\title{
The herbicides trifluralin and tebuthiuron have no genotoxic or mutagenic potential as evidenced by genetic tests
}

\author{
Mariana Furio Franco-Bernardes ${ }^{1}$ Otávio Pelegrino Rocha ${ }^{1} \cdot$ Lilian Cristina Pereira $^{1,2}$. \\ Maria Júlia Tasso $^{3}$ - Gabriela Meireles ${ }^{1}$ - Danielle Palma de Oliveira ${ }^{1,4}$. \\ Daniel Junqueira Dorta ${ }^{3,4}$
}

Received: 27 October 2016 / Accepted: 14 August 2017 / Published online: 6 September 2017

(C) Springer-Verlag GmbH Germany 2017

\begin{abstract}
Brazil has been the largest world consumer of pesticides since 2008, followed by the USA. The herbicides trifluralin and tebuthiuron have been widely applied in agriculture. These herbicides are selective for some plant species, and their use brings various benefits. However, the genotoxic and mutagenic effects of tebuthiuron on non-target organisms are poorly known, and in addition, the effects of trifluralin must be better investigated. Therefore, this study employed genetic tests including the comet assay and micronucleus test to evaluate the genotoxic effects of trifluralin and tebuthiuron on HepG2 cells. In addition, we have used the Ames test to assess the mutagenic effects of the herbicides on the TA97a, TA98, TA100, and TA1535 strains of Salmonella typhimurium. On the basis of the comet assay and the micronucleus test, trifluralin did not cause genetic damage to HepG2 cells. In addition, trifluralin did not impact the tested S. typhimurium strains. Regarding tebuthiuron, literature has
\end{abstract}

Responsible editor: Markus Hecker

Mariana Furio Franco-Bernardes

marianaffranco@yahoo.com.br

Daniel Junqueira Dorta

djdorta@ffclrp.usp.br

1 School of Pharmaceutical Sciences of Ribeirão Preto, University of São Paulo, Av. do café, s/n, Ribeirão Preto, SP 14040-903, Brazil

2 Faculdade de Ciências Agronômicas, Fazenda Experimental de Lageado, Universidade Estadual Paulista "Júlio de Mesquita Filho", Botucatu, SP, Brazil

3 Faculdade de Filosofia, Ciências e Letras de Ribeirão Preto (FFCLRP - USP), Av. Bandeirantes, 3900, Ribeirão Preto, SP 14040-901, Brazil

4 National Institute for Alternative Technologies of Detection, Toxicological Evaluation and Removal of Micropollutants and Radioactives (INCT-DATREM), Unesp, Institute of Chemistry, P.O. Box 355, 14800-900 Araraquara, SP, Brazil shown that this herbicide damaged DNA in Oreochromis niloticus. Nevertheless, we have found that tebuthiuron was not genotoxic to either HepG2 cells or the S. typhimurium strains. Therefore, neither trifluralin nor tebuthiuron exerted genotoxic or mutagenic potential at the tested conditions.

Keywords Comet assay · Micronucleus · Ames test . HepG2 $\cdot$ Salmonella typhimurium

\section{Introduction}

Brazil has been the largest consumer of pesticides since 2008, followed by the USA. In the last decade, the consumption of pesticides in Brazil increased by $190 \%$ compared to previous years, a growth rate that corresponded to more than twice the global market growth rate in that same period (93\%) (Rigotto et al. 2014). The Brazilian consumption of pesticides was 936,000 tons in the 2010/2011 season, amounting to $\$ 8.5$ billion in financial transactions involving ten companies that control $75 \%$ of the pesticide market in the country (ANVISA 2013; Rigotto et al. 2014). Herbicides account for $45 \%$ of the volume of pesticides consumed in Brazil, followed by fungicides (14\%) and insecticides (12\%) (Rigotto et al. 2014).

The herbicides trifluralin and tebuthiuron have been extensively used in Brazil and in other countries, mainly in sugarcane and soybean crops, to control weeds (Lima et al. 2012). According to data from the Brazilian Institute of Environment and Renewable Natural Resources (IBAMA 2017), sales of trifluralin comprised 1467.41 tons in 2012 and 1594.00 tons in 2014. Regarding tebuthiuron, sales comprised 3150.86 tons in 2012 and 3952.54 tons in 2014. In the USA, trifluralin was among the 25 most used pesticides in agriculture, and the estimated usage ranged from 1360.77 to 3175.14 tons in 2012 (EPA 2017). There have been no recent data on the 
amount of tebuthiuron applied annually in the USA. The European Union banned trifluralin and tebuthiuron in 2008 (European Commission 2009) and 2002 (European Commission 2002), respectively.

A large quantity of the total amount of pesticides applied to control weeds and pests reaches the environment and can have undesirable effects on ecosystems and humans (Hernández et al. 2013; Franco-Bernardes et al. 2015). Trifluralin is little soluble in water and binds strongly to soil components, so it does not tend to reach groundwater. Nevertheless, it may contaminate surface water by spray drift or runoff (EPA 1996). In Brazil, trifluralin has been found in surface water and rainwater in the Pantanal region at 0.019 and $0.31 \mu \mathrm{g} / \mathrm{L}$, respectively (Laabs et al. 2002), and has been detected in water resources in the Primavera do Leste region at $0.102 \mu \mathrm{g} / \mathrm{L}$ (Dores et al. 2006). In Canada and Greece, trifluralin has been detected in rivers at $1-2 \mathrm{ng} / \mathrm{L}$ and $0.021 \mu \mathrm{g} / \mathrm{L}$ (Rawn et al. 1999; Albanis et al. 1998), respectively. In China, it has been found in sediment samples of the Bohai and Yellow seas at $0.01 \mu \mathrm{g} / \mathrm{Kg}$ (Zhong et al. 2015). In the USA, a study by the U.S. Geological Survey's (USGS) National Water-Quality Assessment (NAWQA) analyzed the occurrence of pesticides in groundwater and found trifluralin in three of 1270 samples between 2002 and 2011 (Toccalino et al. 2014).

According to EPA (1996), trifluralin ranks as practically nontoxic to birds and mammals on an acute basis. However, for aquatic animals (fish and invertebrates), trifluralin ranks as moderate to highly toxic. The $\mathrm{LC}_{50}$ of trifluralin for rainbow trout and bluegill sunfish is 41 and $58 \mu \mathrm{g} / \mathrm{L}$, respectively. Besides, trifluralin at levels as low as $5.1 \mu \mathrm{g} / \mathrm{L}$ may have chronic effects on fish. This herbicide is also considered highly toxic to estuarine and marine organisms (EPA 1996).

Tebuthiuron can reach the aquatic environment, particularly groundwater, due to its high solubility in water, relatively high persistence, and mobility in soil (EPA 1994). In Brazil, this herbicide has been found at a concentration of up to $0.09 \mu \mathrm{g} / \mathrm{L}$ in outcropping sites of the Guarani Aquifer, one of the most important groundwater reservoirs in the Southern Cone (Gomes et al. 2001). In Australia, tebuthiuron has been detected at concentrations greater than $0.02 \mu \mathrm{g} / \mathrm{L}$ in rivers flowing to the Great Barrier Reef (Lewis et al. 2009). In the USA, the National Water-Quality Assessment (NAWQA) Program has determined tebuthiuron in 38 of 1267 samples of groundwater between 2002 and 2011 (Toccalino et al. 2014).

EPA classifies tebuthiuron as practically nontoxic to birds, fish, and aquatic invertebrates, and slightly toxic to mammals. However, EPA mentions the phytotoxicity of tebuthiuron to on- and off-site endangered terrestrial, semiaquatic, and aquatic plant species as well as concern about its phytotoxicity to off-site non-target plants. Acute toxicity studies have found $\mathrm{LC}_{50}$ values of 143 and $106 \mathrm{mg} / \mathrm{L}$ for rainbow trout and bluegill sunfish, respectively, (EPA 1994).
Because pesticides are released into the environment on a daily basis and can reach non-target organisms, their genetic effects of chemical toxicity become a matter of great concern (Ribas et al. 1996). Experimental findings have revealed that various pesticides display genotoxic or mutagenic properties, which constitute initial risk factors for carcinogenicity in the long term (Mostafalou and Abdollahi 2013).

Several literature studies have evaluated the genotoxic/ mutagenic potential of trifluralin. Pilinskaia (1987) has studied the exposure of human lymphocyte cultures (in vitro) and mouse bone marrow cells (in vivo) to trifluralin and its eight metabolites. Trifluralin itself did not induce chromosome aberrations in the in vitro or in the in vivo models used, but some of its metabolites induced moderate or weak clastogenic effects. Ribas et al. (1995) have observed increased comet tail length in human peripheral blood lymphocytes exposed to trifluralin, which indicates that the herbicide was genotoxic after exposure to concentrations as low as $25 \mu \mathrm{g} / \mathrm{mL}$. In another work, Ribas et al. (1996) did not observe any genotoxic effects of trifluralin regarding chromosome aberrations and micronucleus assays on cultured human peripheral blood lymphocytes. However, they verified that exposure to the herbicide leads to higher frequency of sister-chromatid exchanges at a concentration of $50 \mu \mathrm{g} / \mathrm{mL}$. Gebel et al. (1997) have reported that treatment with trifluralin at $1400 \mathrm{mg} / \mathrm{kg}$ of body weight increases the micronucleus frequency in mouse bone marrow cells in female mice. Konen and Çavas (2008) have shown that both trifluralin and its commercial formulation Treflan at 1,5 , and $10 \mu \mathrm{g} / \mathrm{L}$ increased the frequency of micronuclei in $O$. niloticus peripheral erythrocytes, indicating the mutagenic potential of this herbicide.

Regarding tebuthiuron, only one previous study has assessed the potential of this herbicide to cause genotoxicity and mutagenicity. Franco-Bernardes et al. (2014) have not found any difference in the frequency of micronuclei in $O$. niloticus exposed to tebuthiuron. However, these authors have shown that small fish exposed to tebuthiuron at $125 \mathrm{mg} /$ L had significant higher comet score than the control, which indicated that tebuthiuron may damage DNA.

On the basis of the aforementioned studies, the genotoxic and mutagenic potential of trifluralin to non-target organisms cannot be excluded. In some cases, however, this potential has not been corroborated (Piliskaia 1987; Ribas et al. 1996). In contrast, studies that analyzed the genotoxicity and mutagenicity of tebuthiuron are scarce. Therefore, assessing the ability of these widely used herbicides to damage DNA is clearly necessary.

One test frequently used to evaluate mutations in genes and primary damage to DNA is the Ames test that employs the prokaryote Salmonella typhimurium as it provides results within a short time (Houk 1992). Nevertheless, this test cannot detect chromosomal damage or aneuploidies. In this case, tests that employ eukaryotes are essential, and with which the comet assay and the micronucleus test can be performed. The 
comet assay is a very sensitive method to detect damage to DNA, and it can be carried out on any type of nucleated eukaryotic cell, proliferating or not, in vivo or in vitro (Lee and Steinert 2003). This test does not verify mutations; in fact, it detects genomic lesions that, if not corrected, can be processed into mutations (Kammann et al. 2001). The micronucleus test can be used to assess mutation in eukaryotes because it can spot chromosomal fragments or acentric chromosomes that are not incorporated into the main nucleus after mitosis (Cavalcante et al. 2008). This test is also very sensitive and can be conducted on any type of nucleated eukaryotic cell, in vivo or in vitro (Araldi et al. 2015). Unfortunately, the micronucleus test cannot detect substances that do not break chromosomes or do not cause their loss in the anaphase (Heddle et al. 1983). Despite their individual limitations, together, the comet assay, the micronucleus test, and the Salmonella/microsome assay can help to detect a broad range of chemical substances that can result in genotoxicity/ mutagenicity.

Using the HepG2 cell line during in vitro eukaryotic cell assays is advantageous because this cell line allows for the synthesis and secretion of several of the plasma proteins characteristic of normal human liver cells. In addition, this cell line can express the tumor suppressor protein p53, an essential component of cellular response to DNA damage. Although cell culture systems cannot fully replicate the absorption, distribution, and excretion conditions present in the body, they are valuable tool for screening analyses (O'brien et al. 2000).

Given the intense use of trifluralin and tebuthiuron in the Brazilian agriculture and the lack of studies on the genotoxicity and mutagenicity of these herbicides, we aimed to investigate the potential of trifluralin and tebuthiuron to damage DNA by performing the comet and micronucleus assays on HepG2 cells and Salmonella mutagenicity/microssome assay. We have addressed the hypothesis that both herbicides could have genotoxic and mutagenic potential.

\section{Material and methods}

\section{Chemicals}

The herbicides trifluralin and tebuthiuron, analytical standards in both cases, were purchased from Sigma-Aldrich (St Louis, MO, USA). Trifluralin (catalog \#32061; CAS number 1582-09-8) and tebuthiuron (catalog \#45671; CAS number 34014-18-1). Acridine orange, cytochalasin B, dimethylsulfoxide (DMSO), trypan blue, agarose, and ethidium bromide were also purchased from Sigma Aldrich (St Louis, MO, USA). Minimum Essential Medium (MEM), fetal bovine serum (FBS), and penicillin-streptomycin solution were supplied by Gibco (Carlsbad, CA, USA). The HepG2 cells were obtained from the American Type
Culture Collection, number HB 8065. The Salmonella strains were gently provided by Environmental Agency of São Paulo state (CETESB) - Brazil.

\section{Comet assay}

Cells were cultured in MEM supplemented with 10\% FBS containing $100 \mathrm{IU} / \mathrm{mL}$ penicillin and $100 \mathrm{IU} / \mathrm{mL}$ streptomycin at $37^{\circ} \mathrm{C}$, for $24 \mathrm{~h}$, under flow of $5 \% \mathrm{CO}_{2}$ in air.

Herbicides, dissolved in DMSO were used for the comet assay and for the micronucleus test performed on the HepG2 cell line. The cells were exposed to a maximum concentration of $0.5 \%$ DMSO, and the concentrations of the herbicides were chosen on the basis of their cytotoxicity that was assessed with the MTT cytotoxicity assay, where the cells exposed to trifluralin at 50 and $100 \mu \mathrm{M}$ had decreased cell viability. In contrast, the viability of the cells exposed to tebuthiuron did not change at any of the concentrations tested (data not shown).

The comet assay was performed according to the method described by Tice et al. (2000) with modifications. Approximately $2 \times 10^{5} \mathrm{HepG} 2$ cells in $2 \mathrm{~mL}$ of culture medium supplemented with FBS per well were incubated in 24well plates for $24 \mathrm{~h}$. The cells were exposed to the different concentrations of the herbicides for $4 \mathrm{~h}$.

After exposure, the cells were trypsinized, embedded in $85 \mu \mathrm{L}$ of low-melting-point agarose $0.5 \%$ at $37{ }^{\circ} \mathrm{C}$, and arranged on agarose slides. The slides were placed in a lysis solution $(\mathrm{NaCl} 2.5 \mathrm{M}$; EDTA $100 \mathrm{mM}$; Tris $10 \mathrm{mM}$; Triton $1 \%$; DMSO $10 \%$; pH 10.5) at $4{ }^{\circ} \mathrm{C}$, for $2 \mathrm{~h}$. After lysis, the slides were immersed in alkaline buffer $(\mathrm{NaOH} 10 \mathrm{M}$; EDTA $200 \mathrm{mM}$; pH 13) for $20 \mathrm{~min}$. Then, the slides and the buffer were placed on a horizontal electrophoresis box at $25 \mathrm{~V}$ and $300 \mathrm{~mA}$, for $20 \mathrm{~min}$. After that, the slides were neutralized with Tris $0.4 \mathrm{M}$ ( $\mathrm{pH} 7.5$ ) for $20 \mathrm{~min}$ and fixed in ethanol for $5 \mathrm{~min}$.

Two slides were prepared after each treatment. Fifty nucleoids from each slide were analyzed. The slides were stained with ethidium bromide $(20 \mu \mathrm{g} / \mathrm{mL})$. Analysis was conducted under an Olympus Bx50 fluorescence microscope (Olympus America INC, Melville, NY), at 40× magnification. The Comet IV (Perceptive Instruments Ltd., United Kingdom) software was employed. For this test, DMSO $0.5 \%$ and Methylmethane Sulfonate (MMS) $15 \mu \mathrm{g} / \mathrm{mL}$ were used as the negative and positive controls, respectively.

Cell viability was determined by the exclusive staining method with Trypan Blue (Gibco, $20 \mu \mathrm{L}$ of cell suspension obtained after each treatment and $20 \mu \mathrm{L}$ of $0.4 \%$ Trypan Blue). A limit of $80 \%$ of viable cells was necessary to perform the comet assay (data not shown). Three independent experiments were performed in triplicate (three wells for each concentration), and the results were statistically analyzed in the GraphPrism software, version 5.0 for Windows. Analysis of variance (ANOVA) followed by Dunnet's post-test was employed. Results with $p<0.05$ were considered statistically significant. 


\section{Micronucleus test}

The micronucleus test was conducted as described by Fenech (2000). Approximately $5 \times 10^{5} \mathrm{HepG} 2$ cells in $5 \mathrm{~mL}$ of culture medium supplemented with FBS were incubated in $25-\mathrm{cm}^{3}$ culture flasks for $24 \mathrm{~h}$. The cells were exposed to the different concentrations of the herbicides for $20 \mathrm{~h}$. Then, $50 \mu \mathrm{L}$ of cytochalasin B solution ( $2 \mathrm{mg} / \mathrm{mL}$ ) was added, and the cells were incubated for additional $28 \mathrm{~h}$. Next, the cells were trypsinized and centrifuged at $212 \times g$, for $5 \mathrm{~min}$. The supernatant was removed, and $5 \mathrm{~mL}$ of sodium citrate solution were added to the tubes. The content was homogenized, and $20 \mu \mathrm{L}$ of formaldehyde was added to each tube. The content was homogenized again and centrifuged at $212 \times \mathrm{g}$, for $5 \mathrm{~min}$. The supernatant was discarded, and $5 \mathrm{~mL}$ of a 3:1 methanol/ acetic acid solution was added. The content was homogenized and centrifuged at $212 \times g$, for $5 \mathrm{~min}$. The supernatant was removed, and $50 \mu \mathrm{L}$ of cell suspension was used to prepare the slides. After each treatment, two slides were prepared and stained with acridine orange $(10 \mu \mathrm{g} / \mathrm{mL})$ in phosphate buffer. A total of 500 binucleated cells $(\mathrm{BN})$ were counted in each slide. Therefore, 1000 cells from each tested concentration of herbicide were scored. The presence of micronuclei in binucleated cells was analyzed on each slide, and the number of micronuclei in the treated cells was compared with the number of micronuclei in the negative control-DMSO $0.5 \%$. Doxorubicin $0.03 \mu \mathrm{g} / \mathrm{mL}$ was used as positive control.

After that, 250 cells were counted on each slide to analyze the amount of mono-, bi-, tri-, and polynucleated cells. A total of 500 cells from each tested concentration of herbicide was scored. Then, the nuclear division index (NDI) was calculated by means of the following formula: NDI $=[\mathrm{M} 1+2(\mathrm{M} 2)+$ $3(\mathrm{M} 3)+4(\mathrm{M} 4)] / n$, where M1, M2, M3, and M4 represent the cells with one, two, three, or more nuclei, respectively, and $n$ is the total number of counted cells. This index provides a measure of the proliferative status of viable cells and the percentage of binucleated cells. According to Fenech (2000), an amount of binucleated cells $(\mathrm{BN})$ above $35 \%$ is required for the experiment. If this percentage is not reached, the experiment is discharged and replaced.

Three independent experiments were performed in triplicate (three wells for each concentration), and the results were statistically analyzed in the GraphPrism software, version 5.0 for Windows. Analysis of variance (ANOVA) followed by Dunnet's post-test was employed. Results with $p<0.05$ were considered statistically significant.

\section{Salmonella/microsome assay}

For the Salmonella/microsome assay, the pre-incubation protocol reported by Maron and Ames (1983) and incorporated in Bacterial Reverse Mutation Test guideline OECD 471 (1997) was used. The $S$. typhimurium strains TA98 (hisD3052, rfa,
$\Delta$ bio, $\Delta$ uvrB, pKM101-which detects frameshift mutations), TA100 (hisG46, rfa, $\Delta$ bio, $\Delta$ uvrB, pKM101-which detects base-pair substitution mutations), TA97a (hisD6610, rfa, $\Delta$ bio, $\Delta$ uvrB, pKM101 - which detects frameshift mutations), and TA1535 (hisG46, rfa, $\Delta$ bio, $\Delta$ uvrB - which detects base-pair substitution mutations) were employed. The herbicides were tested at different concentrations in the presence and in the absence of the exogenous metabolizing system (S9) mix. The concentrations of pesticides were chosen on the basis of OECD 471 (OECD 1997), which recommends at least five concentrations of tested substance with the maximum dose at $5000 \mu \mathrm{g} /$ plate. Initially, the tests were carried out on the TA 98 and TA 100 strains, which can detect about $90 \%$ of the mutagens in a population (Mortelmans and Zeiger 2000). For these strains, the minimum tested concentration of each herbicide was $0.01 \mu \mathrm{g} /$ plate. The assay was also carried out on the TA97a and TA1535 lines because the OECD recommends performing this test with a minimum of four lines (OECD 1997). On the basis of the negative results obtained in the tests conducted with TA98 and TA100, the minimum tested concentration of each herbicide in TA97a and TA1535 was $10 \mu \mathrm{g} /$ plate. The herbicides were cytotoxic at concentrations of tebuthiuron and trifluralin of $5000 \mu \mathrm{g} /$ plate and in the presence of the S9 mix for the TA98 strain, and at concentrations of tebuthiuron of $5000 \mu \mathrm{g} /$ plate and in the presence of the S9 mix for the TA97a strain, which prevented us from counting the revertants in these tests (Tables 1 and 2).

Petri dishes were prepared with minimal agar, and the Salmonella strains were cultivated and maintained in optimal proliferation conditions (in nutrient broth at $37{ }^{\circ} \mathrm{C}$ in the shaker) overnight. After this period, for the assay conducted in the absence of the $\mathrm{S} 9 \mathrm{mix}, 100 \mu \mathrm{L}$ of the strain culture ( $10^{9}$ cells), $100 \mu \mathrm{L}$ of the sample, and $500 \mu \mathrm{L}$ of phosphate buffer $0.2 \mathrm{mM}$ were added to a test tube. For the assay in the presence of the S9 mix, $100 \mu \mathrm{L}$ of the strain culture $\left(10^{9}\right.$ cells), $100 \mu \mathrm{L}$ of the sample, and $500 \mu \mathrm{L}$ of S9 mix (4\%) were added to the test tubes. Subsequently, the test tubes were incubated at $37{ }^{\circ} \mathrm{C}$ for $30 \mathrm{~min}$. Then, $2 \mathrm{~mL}$ of surface agar were added to each tube. The contents of each test tube were placed in the respective petri dish, which was then incubated at $37^{\circ} \mathrm{C}$ for $66 \mathrm{~h}$. After incubation, the number of revertant colonies was counted by hand, and the results were expressed as number of revertants per plate. The background was carefully evaluated.

For the negative control, $100 \mu \mathrm{L}$ of DMSO was used. The positive controls employed in the absence of the S9 mix were $0.5 \mu \mathrm{g} /$ plate of 4-nitroquinoline oxide for the TA98 and TA100 strains, $5 \mu \mathrm{g} /$ plate of 4-nitroquinoline oxide for the TA97a strain, and $5 \mu \mathrm{g} /$ plate of sodium azide for the TA1535 strain. The positive control used in the presence of the S9 mix was $2.5 \mu \mathrm{g} /$ plate of 2 -aminoanthracene for all the tested strains.

A single experiment with the $\mathrm{S} 9$ mix was performed in triplicate (three plates for each concentration) on each strain, and a single experiment without the $\mathrm{S} 9$ mix was performed in triplicate on each strain, too. Statistical analysis was 
Table 1 Average and standard deviation of histidine-positive revertants in the Salmonella/microsome assay performed on the S. typhimurium strains TA98, TA100, TA97a, and TA1535 exposed to trifluralin concentrations ranging from 0.01 to $5000 \mu \mathrm{g} /$ plate in DMSO for $66 \mathrm{~h}$. The negative control was $100 \mathrm{uL}$ of DMSO. The positive control used in the absence of the S9 mix was $0.5 \mu \mathrm{g} /$ plate of 4-nitroquinoline oxide for the TA98 and TA100 strains, $5 \mu \mathrm{g} /$ plate of 4-nitroquinoline oxide for the TA97a strain, and $5 \mu \mathrm{g} /$ plate of sodium azide for the TA1535 strain. The positive control used in the presence of S9 was $2.5 \mu \mathrm{g} /$ plate of 2 aminoanthracene for all the tested strains

\begin{tabular}{|c|c|c|c|c|c|c|c|c|}
\hline \multirow{2}{*}{$\begin{array}{l}\text { Concentration } \\
(\mu \mathrm{g} / \text { plate })\end{array}$} & \multicolumn{2}{|l|}{ TA 98} & \multicolumn{2}{|l|}{ TA 100} & \multicolumn{2}{|l|}{ TA97a } & \multicolumn{2}{|l|}{ TA1535 } \\
\hline & Absence of S9 & Presence of S9 & Absence of S9 & Presence of S9 & Absence of S9 & Presence of S9 & Absence of S9 & Presence of S9 \\
\hline $\begin{array}{l}\text { Negative } \\
\text { control }\end{array}$ & $33.8 \pm 4.4$ & $47.0 \pm 6.9$ & $207.8 \pm 7.0$ & $229.8 \pm 24.6$ & $168.0 \pm 15.1$ & $168.8 \pm 9.9$ & $10.0 \pm 2.1$ & $7.8 \pm 1.8$ \\
\hline 0.01 & $33.7 \pm 3.1$ & $54.3 \pm 3.2$ & $241.0 \pm 7.8$ & $261.5 \pm 29.0$ & $-^{\mathrm{c}}$ & $-^{\mathrm{c}}$ & $-^{\mathrm{c}}$ & $-^{\mathrm{c}}$ \\
\hline 0.1 & $38.7 \pm 7.8$ & $44.0 \pm 13.1$ & $221.0 \pm 8.5$ & $255.7 \pm 4.7$ & $-^{\mathrm{c}}$ & $-^{\mathrm{c}}$ & $-^{\mathrm{c}}$ & $-^{\mathrm{c}}$ \\
\hline 1 & $35.7 \pm 7.2$ & $48.3 \pm 9.9$ & $211.0 \pm 9.2$ & $250.0 \pm 5.0$ & $-^{\mathrm{c}}$ & $-^{\mathrm{c}}$ & $-^{\mathrm{c}}$ & $-^{\mathrm{c}}$ \\
\hline 10 & $33.3 \pm 6.7$ & $54.3 \pm 6.7$ & $218.0 \pm 9.9$ & $235.0 \pm 19.1$ & $181.7 \pm 11.0$ & $153.0 \pm 24.0$ & $10.0 \pm 2.0$ & $7.0 \pm 4.0$ \\
\hline 100 & $30.5 \pm 9.2$ & $44.7 \pm 6.4$ & $222.0 \pm 6.2$ & $255.3 \pm 11.1$ & $182.7 \pm 13.6$ & $202.7 \pm 9.3$ & $12.3 \pm 4.7$ & $13.0 \pm 1.7$ \\
\hline 1000 & $29.3 \pm 6.4$ & $41.3 \pm 6.5$ & $203.0 \pm 16.5$ & $254.3 \pm 12.7$ & $153.0 \pm 15.6$ & $167.3 \pm 16.3$ & $16.0 \pm 5.0$ & $10.3 \pm 3.8$ \\
\hline 2500 & $33.7 \pm 0.6$ & $49.4 \pm 7.2$ & $199.3 \pm 5.5$ & $-^{c}$ & $184.0 \pm 23.5$ & $-^{\mathrm{c}}$ & $8.0 \pm 3.0$ & $10.3 \pm 2.1$ \\
\hline 5000 & $39.0 \pm 6.0$ & $-{ }^{\mathrm{b}}$ & $179.0 \pm 1.0$ & $224.0 \pm 3.0$ & $174.0 \pm 5.0$ & $202.3 \pm 16.0$ & $16.0 \pm 0.0$ & $13.3 \pm 2.1^{\mathrm{a}}$ \\
\hline $\begin{array}{l}\text { Positive } \\
\text { control }\end{array}$ & $540.0 \pm 104.6^{\mathrm{a}}$ & $3944 \pm 33.9^{\mathrm{a}}$ & $2216 \pm 837.2^{\mathrm{a}}$ & $3464 \pm 169.7^{\mathrm{a}}$ & $572.0 \pm 24.0^{\mathrm{a}}$ & $1944 \pm 396.0^{\mathrm{a}}$ & $982.5 \pm 51.6^{\mathrm{a}}$ & $1412 \pm 198.0^{\mathrm{a}}$ \\
\hline
\end{tabular}

${ }^{\text {a }}$ Significant statistical difference as compared to the negative control and revealed by the software Salanal. The Bernstein model was employed

${ }^{\mathrm{b}}$ The observed toxicity prevented us from counting the bacteria

${ }^{\mathrm{c}}$ Not tested

conducted for each strain tested with the S9 mix and for each strain tested without the $\mathrm{S} 9$ mix. The data were expressed by the slope of the graphs and were analyzed with the software Salanal, a statistical program developed by the Integrated Laboratory Systems, Research Triangle Park, N.C., USA. The Bernstein model was employed. This model uses both ANOVA and linear regression.

Table 2 Average and standard deviation of histidine-positive revertants in the Salmonella/microsome assay performed on the $S$. typhimurium strains TA98, TA100, TA97a, and TA1535 exposed to tebuthiuron concentrations ranging from 0.01 to $5000 \mu \mathrm{g} / \mathrm{plate}$ in DMSO for $66 \mathrm{~h}$. The negative control was $100 \mathrm{uL}$ of DMSO. The positive control used in the

\section{Results}

The comet assay aided analysis of the genotoxicity of trifluralin and tebuthiuron, at various concentrations, toward HepG2 cells. The tail moment values of the cells exposed to both herbicides were not statistically different from the tail moment values of the cells belonging to the negative control

absence of the S9 mix was $0.5 \mu \mathrm{g} /$ plate of 4-nitroquinoline oxide for the TA98 and TA100 strains, $5 \mu \mathrm{g} /$ plate of 4-nitroquinoline oxide for the TA97a strain, and $5 \mu \mathrm{g} /$ plate of sodium azide for the TA1535 strain. The positive control used in the presence of S9 was $2.5 \mu \mathrm{g} /$ plate of 2 aminoanthracene for all the tested strains

\begin{tabular}{|c|c|c|c|c|c|c|c|c|}
\hline \multirow{2}{*}{$\begin{array}{l}\text { Concentration } \\
(\mu \mathrm{g} / \text { plate })\end{array}$} & \multicolumn{2}{|l|}{ TA 98} & \multicolumn{2}{|l|}{ TA 100} & \multicolumn{2}{|l|}{ TA97a } & \multicolumn{2}{|l|}{ TA1535 } \\
\hline & Absence of S9 & Presence of S9 & Absence of S9 & Presence of S9 & Absence of S9 & Presence of S9 & Absence of S9 & Presence of S9 \\
\hline $\begin{array}{l}\text { Negative } \\
\text { control }\end{array}$ & $33.8 \pm 4.4$ & $47.0 \pm 6.9$ & $207.8 \pm 7.0$ & $229.8 \pm 24.6$ & $168.0 \pm 15.1$ & $168.8 \pm 9.9$ & $10.0 \pm 2.1$ & $7.8 \pm 1.8$ \\
\hline 0.01 & $33.7 \pm 3.1$ & $49.7 \pm 3.2$ & $189.3 \pm 21.4$ & $253.0 \pm 17.4$ & $-^{\mathrm{c}}$ & $-^{\mathrm{c}}$ & $-^{\mathrm{c}}$ & $-^{\mathrm{c}}$ \\
\hline 0.1 & $38.7 \pm 7.8$ & $52.0 \pm 3.6$ & $204.7 \pm 17.4$ & $253.7 \pm 21.1$ & $-^{\mathrm{c}}$ & $-^{\mathrm{c}}$ & $-^{\mathrm{c}}$ & $-^{\mathrm{c}}$ \\
\hline 1 & $35.7 \pm 7.2$ & $50.0 \pm 1.4$ & $193.5 \pm 2.1$ & $235.0 \pm 7.2$ & $-^{\mathrm{c}}$ & $-^{\mathrm{c}}$ & $-^{\mathrm{c}}$ & $-^{\mathrm{c}}$ \\
\hline 10 & $33.3 \pm 6.7$ & $54.0 \pm 6.1$ & $196.0 \pm 5.7$ & $241.0 \pm 6.1$ & $178.7 \pm 23.5$ & $195.7 \pm 4.5$ & $10.3 \pm 4.0$ & $7.7 \pm 5.5$ \\
\hline 100 & $30.5 \pm 9.2$ & $53.7 \pm 6.1$ & $200.7 \pm 5.9$ & $245.7 \pm 19.0$ & $174.3 \pm 12.9$ & $166.7 \pm 37.7$ & $9.0 \pm 1.7$ & $6.0 \pm 4.0$ \\
\hline 1000 & $29.3 \pm 6.4$ & $58.3 \pm 1.5$ & $201.7 \pm 8.4$ & $232.7 \pm 11.6$ & $166.0 \pm 18.0$ & $187.5 \pm 6.4$ & $15.0 \pm 5.6$ & $14.0 \pm 2.6$ \\
\hline 2500 & $37.3 \pm 4.5$ & $59.1 \pm 3.4$ & $209.7 \pm 8.5$ & $-^{\mathrm{c}}$ & $157.7 \pm 24.0$ & $201.0 \pm 31.8$ & $18.3 \pm 2.5$ & $15.3 \pm 5.1$ \\
\hline 5000 & $-{ }^{\mathrm{b}}$ & b & $141.3 \pm 36.5$ & $199.0 \pm 25.0$ & $126.0 \pm 8.5$ & ${ }^{\mathrm{b}}$ & $16.3 \pm 7.5$ & $18.0 \pm 2.0^{\mathrm{a}}$ \\
\hline $\begin{array}{l}\text { Positive } \\
\text { control }\end{array}$ & $540.0 \pm 104.6^{\mathrm{a}}$ & $3944 \pm 33.9 \mathrm{a}$ & $2216 \pm 837.2^{\mathrm{a}}$ & $3464 \pm 169.7^{\mathrm{a}}$ & $572.0 \pm 24.0^{\mathrm{a}}$ & $1944 \pm 396.0^{\mathrm{a}}$ & $982.5 \pm 51.6^{\mathrm{a}}$ & $1412 \pm 198.0^{\mathrm{a}}$ \\
\hline
\end{tabular}

${ }^{a}$ Significant statistical difference as compared to the negative control and revealed by the software Salanal. The Bernstein model was employed

${ }^{\mathrm{b}}$ The observed toxicity prevented us from counting the bacteria

${ }^{\mathrm{c}}$ Not tested 

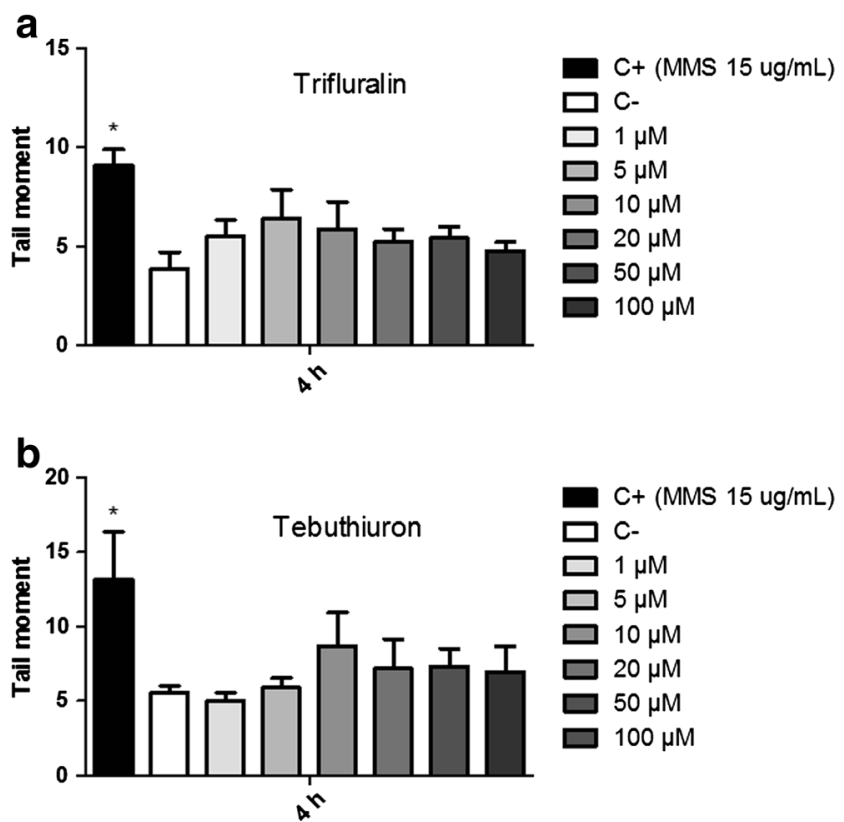

Fig. 1 Comet assay performed on HepG2 cells. The cells were exposed to herbicides at concentrations of $1,5,10,20,50$, or $100 \mathrm{uM}$ in DMSO $(0.5 \%)$ for 4 h. $n=3$. a HepG2 cells exposed to trifluralin. b HepG2 cells exposed to tebuthiuron. *Significant statistical difference as compared to the negative control and revealed by using ANOVA followed by Dunnet's test $(p<0.05)$

group. Therefore, the comet assay indicated that neither trifluralin nor tebuthiuron (at concentrations of 1, 5, 10, 20, 50, and $100 \mu \mathrm{M}$ ) were genotoxic to HepG2 cells (Fig. 1).

With respect to the micronucleus test, the nuclear division index (NDI) of the cells belonging to the negative control groups
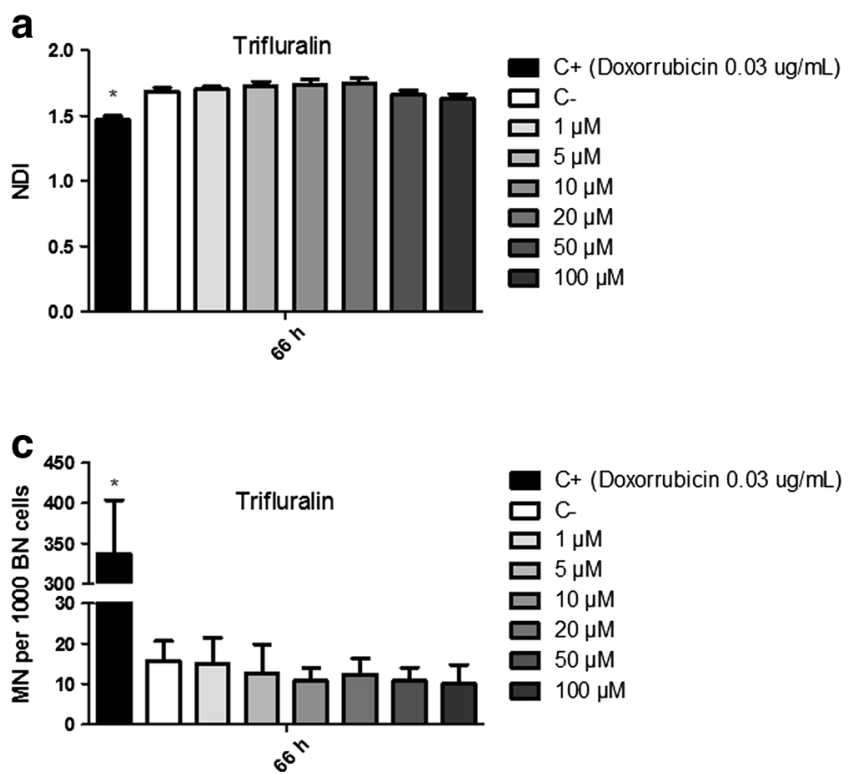

Fig. 2 Micronucleus test performed on HepG2 cells. The cells were exposed to the herbicides at concentrations of $1,5,10,20,50$, or $100 \mathrm{uM}$, in DMSO (0.5\%), for 66 h. $n=3$. a Nuclear division index (NDI) of HepG2 cells exposed to trifluralin. b NDI of HepG2 cells exposed to tebuthiuron. $\mathbf{c}$ Number of micronuclei in HepG2 cells exposed to of the cells exposed to trifluralin and tebuthiuron were not significantly different. In addition, the frequency of micronuclei did not differ significantly between the negative control group and the groups treated with the herbicides, indicating that neither trifluralin nor tebuthiuron (at concentrations of 1, 5, 10, 20, 50, and $100 \mu \mathrm{M}$ ) induced mutagenicity in HepG2 cells (Fig. 2).

In the Salmonella/microsome assay, the number of histidine-positive colonies (revertant colonies) tested with the herbicides was similar to those observed in the negative control for all the tested strains, in the presence and in the absence of S9 (Tables 1 and 2). Despite the statistically significant difference observed for the concentration of herbicide of $5000 \mu \mathrm{g} / \mathrm{plate}$ in the case of the TA1535 strain in the presence of the S9 mix, we can consider that both results were negative on the basis of the low mutagenic potency of both compounds: 0.002518 and 0.001004 for tebuthiuron and trifluralin, respectively.

\section{Discussion and conclusion}

The herbicides studied herein are selective for some plant species: trifluralin inhibits cell division (EPA 1996), whereas tebuthiuron inhibits photosynthesis (EPA 1994). However, these herbicides can reach the environment where non-target organisms become exposed, including humans, and where they can exert toxic effects by mechanisms other than the mechanism of their herbicidal action, including genotoxicity/ mutagenicity (Bony et al. 2008).
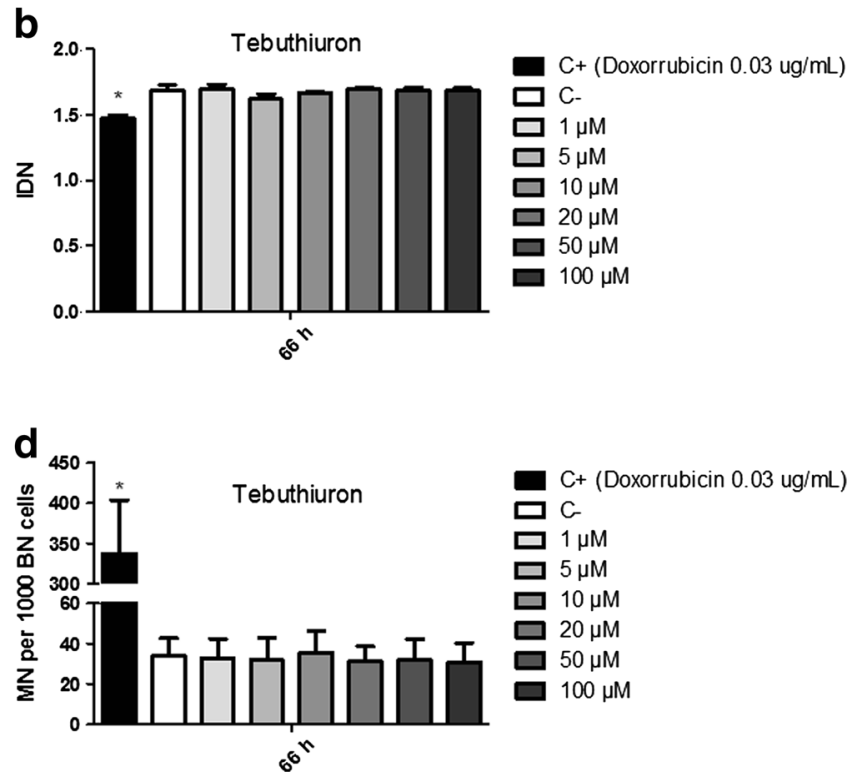

trifluralin. d Number of micronuclei in HepG2 cells exposed to tebuthiuron. *Significant statistical difference as compared to the negative control and revealed by using ANOVA followed by Dunnet's test $(p<0.05)$ 
To analyze the potential of trifluralin and tebuthiuron to damage DNA, we have used HepG2 cells as an in vitro model for eukaryotic cells. The results of the comet assay and the statistical analysis indicated that neither of the tested herbicides was genotoxic. Genotoxicity did not emerge even at the highest tested concentration of $100 \mu \mathrm{M}$. The alkaline version of the test can detect damage such as single, double, and alkali-labile splits (Singh et al. 1988). Similarly, under the tested conditions, the micronucleus test indicated absence of mutagenicity due to breakage or chromosome loss.

We tested concentrations of $1,5,10,20,50$, and $100 \mu \mathrm{M}$ of each herbicide in the comet assay and in the micronucleus test conducted on HepG 2 cells. For trifluralin, these concentrations correspond to $0.33,1.67,3.35,6.70,16.76$, and $33.52 \mathrm{mg} / \mathrm{L}$, respectively. For tebuthiuron, these concentrations correspond to $0.22,1.14,2.28,4.56,11.41$, and $22.8 \mathrm{mg} / \mathrm{L}$, respectively. These concentrations are high compared to the concentrations of these herbicides in the environment, which range from about $2 \mathrm{ng} \mathrm{L}$ to $0.31 \mu \mathrm{g} / \mathrm{L}$ herbicide in surface and groundwater (Albanis et al. 1998; Rawn et al. 1999; Gomes et al. 2001; Laabs et al. 2002; Lewis et al. 2009; Zhong et al. 2015). Given that we have not found any evidence of genotoxicity/ mutagenicity during exposure of HepG2 cells to the herbicides, we can hypothesize that environmentally relevant concentrations of trifluralin and tebuthiuron do not damage DNA in non-target organisms. Nevertheless, it is worth mentioning that although HepG 2 cells express protein p53 and represent a valuable model to analyze damage to DNA, the in vitro system cannot represent the complex properties of whole organisms.

The present study has provided negative results regarding the genotoxicity/mutagenicity of trifluralin and tebuthiuron, which differ from the results of Ribas et al. (1995). Our results also contrast with the findings of Ribas et al. (1996) concerning the sister-chromatid exchanges test. In addition, our results differ from the findings of Gebel et al. (1997) and Konen and Çavas (2008), who demonstrated the genotoxic/mutagenic potential of trifluralin. Gebel et al. (1997), however, used concentrations much higher than the ones used in the present study, and which are even further outside any environmental relevant concentration range. On the other hand, our results agree with the data published by Pilinskaia (1987) and Ribas et al. (1996) in terms of chromosome aberrations and micronucleus assays, for which trifluralin tests negative.

As for the comet assay, results of the present study are not in line with the report of Franco-Bernardes (2014), who indicated that tebuthiuron, which, different from the present work, was tested as the complex commercial mixture, had genotoxic potential. However, our results agree with the same report of Franco-Bernardes (2014) with respect to the micronucleous test, which had not detected any mutagenicity caused by tebuthiuron.

We have also evaluated how trifluralin and tebuthiuron affect the S. typhimurium strains TA98, TA100, TA97a, and
TA1535, in the presence or in the absence of the S9 mix, but we did not detect any mutagenicity. Although we have verified a statistically significant mutagenic effect in bacteria of the TA1535 line exposed to $5000 \mu \mathrm{g} /$ plate of tebuthiuron and trifluralin, this effect makes nois unlikely to be of any biological relevance because the mutagenic potency was very low. Hence, we can consider that the results regarding mutagenicity are all negative and corroborate the findings of Garriott et al. (1991), who have tested the mutagenic potential of trifluralin toward the $S$. typhimurium strains TA98, TA100, TA1535, TA1537, and TA1538 at concentrations of the herbicide ranging from 25 to $400 \mu \mathrm{g} /$ plate in the non-activated test and from 50 to $800 \mu \mathrm{g} /$ plate in the test with metabolic activation. These authors have not detected any reverse mutations in the evaluated $S$. typhimurium strains.

Besides, in 1991, the International Agency on Cancer Research classified trifluralin as group 3 (not classifiable as to its carcinogenicity to humans) (IARC 1991) on the basis of different studies, specially a work showing that the incidence of neoplasms in mice treated with this herbicide does not increase. Therefore, our results are in line with this classification criterion.

Contrary to our expectations, all the data of the present work showed that trifluralin and tebuthiuron do not have genotoxic or mutagenic potentials, as revealed by the genotoxicity and mutagenicity tests conducted on HepG2 cells and $S$. typhimurium strains. Considering the fact that trifluralin and tebuthiuron have been found in important water resources, the negative results regarding its potential to damage DNA represent optimistic data. Nevertheless, we should analyze these negative results with caution because other authors have demonstrated that trifluralin and tebuthiuron display some genotoxic/mutagenic potential; however, most of these studies reported effects at even greater and non-environmentally relevant concentrations compared to our study. Furthermore, to validate these herbicides as genotoxically/mutagenically safe, we have to account for other variables such as tests with chronic exposures to low doses of the herbicides, which represent a more realistic exposure scenario in the environment.

The Europe Union has banished trifluralin and tebuthiuron, but these herbicides are still extensively used in many countries, including Brazil and the USA. Of the total herbicides consumed worldwide, 36, 27, 17, 13, and 7\% are consumed by developed countries, Latin America, Europe, Asia, and Africa, respectively (WAP 2014; Hossain 2016). Together, developed countries and Latin America account for the majority of the global consumption of herbicides. If we remember that Brazil is the largest consumer of pesticides, followed by the USA, studies analyzing the toxic potential of these substances are extremely important, and the negative results reported herein add valuable information about the impact of trifluralin and tebuthiuron. 
Acknowledgements The opinions, assumptions, and conclusions expressed in this material are those of the authors and do not necessarily reflect the views of FAPESP.

Also, the authors wish to thank the Environmental Agency of São Paulo (Companhia Ambiental do Estado de São Paulo - CETESB) for providing the Salmonella strains. This article does not necessarily reflect the view of CETESB and no official endorsement should be inferred.

Funding The authors would like to thank the Brazilian foundation "Fundação de Amparo à Pesquisa do Estado de São Paulo - FAPESP" (2012/15220-3) for their financial support for this project.

\section{References}

Albanis TA, Hela DG, Sakellarides TM, Konstantinou IK (1998) Monitoring of pesticide residues and their metabolites in surface and underground waters of Imathia (N. Greece) by means of solidphase extraction disks and gas chromatography. J Chromatogr A 823(1):59-71. https://doi.org/10.1016/S0021-9673(98)00304-5

ANVISA. Agência Nacional de Vigilância Sanitária (2013) Programa de Análise de Resíduos de Agrotóxicos em Alimentos (PARA). Relatório de Atividades de 2011 e 2012. http://portal.anvisa.gov. br/documents/111215/117818/Resultado\%2B2011-2012 30-10-13. pdf/1b4b6aba-d663-431c-b230-6caa570792a0. Accessed 10 May 2017

Araldi RP, Melo TC, Mendes TB, Sá Júnior PL, Nozima BHN, Ito ET, Carvalho RF, Souza EB, Stocco RC (2015) Using the comet and micronucleous assay for genotoxicity studies: a review. Biomed Pharmacother 72:74-82. https://doi.org/10.1016/j.biopha.2015.04. 004

Bony S, Gillet C, Bouchez A, Margoum C, Devaux A (2008) Genotoxic pressure of vineyard pesticides in fish: field and mesocosm surveys. Aquat Toxicol 89:197-203. https://doi.org/10.1016/j.aquatox.2008. 06.017

Cavalcante DGSM, Martinez CBR, Sofia SH (2008) Genotoxic effects of roundup ${ }^{\circledR}$ on the fish Prochilodus lineatus. Mutat Res 655:41-46. https://doi.org/10.1016/j.mrgentox.2008.06.010

Dores EF, Navickiene S, Cunha ML, Carbo L, Ribeiro ML, DeLamonica-Freire EM (2006) Multiresidue determination of herbicides in environmental waters from primavera do Leste region (middle west of Brazil) by SPE-GC-NPD. J Braz Chem Soc 17(5):866873. https://doi.org/10.1590/S0103-50532006000500008

EPA. Environmental Protection Agency (1994) Reregistration Eligibility Decision (RED) Tebuthiuron. https://www3.epa.gov/pesticides/ chem_search/reg_actions/reregistration/red_PC-105501_15-Jun94.pdf. Accessed 06 May 2017

EPA. Environmental Protection Agency (1996) Reregistration Eligibility Decision (RED) Trifluralin. https://www3.epa.gov/pesticides/ chem_search/reg actions/reregistration/red_PC-036101_1-Apr-96. pdf. Accessed 06 May 2017

EPA. Environmental Protection Agency (2017) Pesticides industry. Sales and usage 2008-2012 market estimates. https:/www.epa.gov/sites/ production/files/2017-01/documents/pesticides-industry-salesusage-2016_0.pdf. Accessed 09 May 2017

European Comission (2002) Pesticide Database. Tebuthiuron. http://ec. europa.eu/food/plant/pesticides/eu-pesticides-database/public/? event $=$ activesubstance.detail\&language $=\mathrm{EN} \&$ selectedID $=1915$. Accessed 09 May 2017

European Comission (2009) Pesticide Database. Trifluralin. http://ec. europa.eu/food/plant/pesticides/eu-pesticides-database/public/? event $=$ activesubstance . detail\&language $=E N \&$ selectedID $=1994$. Accessed 08 May 2017
Fenech M (2000) The in vitro micronucleus technique. Mutat Res 455: 81-95. https://doi.org/10.1016/S0027-5107(00)00065-8

Franco-Bernardes MF, Maschio LR, Azeredo-Oliveira MTV, Almeida EA (2014) Biochemical and genotoxic effects of a commercial formulation of the herbicide tebuthiuron in Oreochromis niloticus of different sizes. Ecotoxicol Environ Contam 9(1):59-67. https://doi. org/10.5132/eec.2014.01.008

Franco-Bernardes MF, Pazin M, Pereira LC, Dorta DJ (2015) Impact of pesticides on environmental and human health. In: Andreazza AC, Scola G (Eds).Toxicology studies - cells, drugs and environment. In tech. doi:https://doi.org/10.5772/59710

Garriott ML, Adams ER, Probst GS, Emmerson JL, Oberly TJ, Kindig DEF, Neal SB, Bewsey BJ, Rexroat MA (1991) Genotoxicity studies on the preemergence herbicide trifluralin. Mutat Res 260:187193. https://doi.org/10.1016/0165-1218(91)90007-9

Gebel T, Kevekortes S, Pav K, Edenharder R, Dunkelberg H (1997) In vivo genotoxicity of selected herbicides in the mouse bonemarrow micronucleus test. Arch Toxicol 71:193-197. https://doi. org/10.1007/s002040050375

Gomes MAF, Spadotto CA, Lanchote VL (2001) Ocorrência do herbicida tebuthiuron na água subterrânea da microbacia do Córrego Espraiado. Ribeirão Preto-SP Pesticidas: R Ecotoxicol e Meio Ambiente 11:65-76. https://doi.org/10.5380/pes.v11i0.3136

Heddle JA, Hite M, Jrkhart B, Macgregor JT, Salamone MF (1983) The indution of micronuclei as a measure of genotoxicity. Mutat Res 123:61-118. https://doi.org/10.1016/0165-1110(83)90047-7

Hernández AF, Parrón T, Tsatsakis AM, Requena M, Alarcón R, LópezGuarnido O (2013) Toxic effects of pesticide mixtures at a molecular level: their relevance to human health. Toxicology 307:136-145. https://doi.org/10.1016/j.tox.2012.06.009

Hossain MM (2016) Recent perspective of herbicide: review of demand and adoption in world agriculture. J Bangladesh Agric Univ 13(1): 19-30. https://doi.org/10.3329/jbau.v13i1.28707

Houk VS (1992) The genotoxicity of industrial wastes and effluents: a review. Mutat Res Rev Genet Toxicol 277(2):91-138. https://doi. org/10.1016/0165-1110(92)90001-P

IARC, International Agency on Cancer Research (1991) Monographs on the evaluation of carcinogenic risks to humans. Trifluralin 53:515534

IBAMA. Instituto Brasileiro do Meio Ambiente e dos Recursos Naturais Renováveis (2017) Relatórios de comercialização de agrotóxicos. http://www.ibama.gov.br/relatorios/substancias-quimicas/relatoriosde-comercializacao-de-agrotoxicos\#boletinsanuais. Accessed 10 May 2017

Kammann U, Bunke M, Steinhart H, Theobald N (2001) A permanent fish cell line (EPC) for genotoxicity testing of marine sediments with the comet assay. Mutat Res 498:61-77. https://doi.org/10.1016/ S1383-5718(01)00268-6

Konen S, Çavas T (2008) Genotoxicity testing of the herbicide trifluralin and its commercial formulation treflan using the piscine micronucleus test. Environ Mol Mutagen 49:434-438. https://doi.org/10. 1002/em.20401

Laabs V, Amelung W, Pinto A, Wantzen M, Silva CJ (2002) Zech W (2002) pesticides in surface water, sediment, and rainfall of the northeastern Pantanal Basin. Brazil J Environ Qual 31:1636-1648. https://doi.org/10.2134/jeq2002.1636

Lee RF, Steinert S (2003) Use of the single cell gel electrophoresis/comet assay for detecting DNA damage in aquatic (marine and freshwater) animals. Mutat Res Rev Mutat Res 544(1):43-64. https://doi.org/10. 1016/S1383-5742(03)00017-6

Lewis SE, Brodie JE, Bainbridge ZT, Rohde KW, Davis AM, Masters BL, Maughan M, Devlin MJ, Mueller JF, Schaffelke B (2009) Herbicides: a new threat to the great barrier reef. Environ Pollut 157(8):2470-2484. https://doi.org/10.1016/j.envpol.2009.03.006

Lima PLR, Magalhães CAS, Carvalho RF, Lima LA, Lima JM, Andrade LAB (2012) Trifluralin leaching in soils cultivated with sugarcane 
irrigated by sub-surface drip system. Irriga. Braz J Irrig Drain 17(1): 39-45. 10.15809/irriga.2012v17n1p39

Maron DM, Ames BN (1983) Revised methods for the salmonella mutagenicity test. Mutat Res 113:173-215. https://doi.org/10.1016/01651161(83)90010-9

Mortelmans K, Zeiger E (2000) The Ames salmonella/microsome mutagenicity assay. Mutat Res 455:29-60. https://doi.org/10.1016/ S0027-5107(00)00064-6

Mostafalou S, Abdollahi M (2013) Pesticides and human chronic diseases: evidences, mechanisms, and perspectives. Toxicol Appl Pharmacol 268:157-177. https://doi.org/10.1016/j.taap.2013.01. 025

O'brien NM, Woods JA, Aherne SA, O'callaghan YC (2000) Cytotoxicity, genotoxicity and oxidative reactions in cell-culture models: modulatory effects of phytochemicals. Biochem Soc Trans 28(2):22-26. https://doi.org/10.1042/bst0280022

OECD. Organization for Economic Cooperation and Development (1997) Guideline for the testing of chemicals. Bacterial Reverse Mutation Test. July 471, 1997. http://www.oecd.org/chemicalsafety/riskassessment/1948418.pdf. Accessed 05 May 2017

Pilinskaia MA (1987) Evaluation of the cytogenetic effect of the herbicide treflan and of a number of its metabolites on mammalian somatic cells. Tsit Genet 21:131-135

Rawn DFK, Halldorson THJ, Woychuck RN, Muir DCG (1999) Pesticides in the Red River and its tributaries in southern Manitoba, 1993-95. Water Qual Res J Can 34(2):183-219 http:/ digital.Library.Mcgill.Ca/WQRJ/pdfs/WQRJ_Vol_34_No_2_Art_ 01.Pdf. Accessed 28 june 2016

Ribas G, Frenzilli G, Barale R, Marcos R (1995) Herbicide-induced DNA damage in human lymphocytes evaluated by the single-cell gel electrophoresis (SCGE) assay. Mutat Res 344:41-54. https://doi. org/10.1016/0165-1218(95)90037-3

Ribas G, Surralles J, Carbonell E, Xamena N, Creus A, Marcos R (1996) Genotoxic evaluation of the herbicide trifluralin on human lymphocytes exposed in vitro. Mutat Res 371:15-21. https://doi.org/10. 1016/S0165-1218(96)90090-7

Rigotto RM, Vasconcelos DP, Rocha MM (2014) Pesticide use in Brazil and problems for public health. Cad Saúde Pública, Rio de Janeiro 30(7):1-3. https://doi.org/10.1590/0102-311XPE020714

Singh NP, Mccoy MT, Tice RRE, Schneider EL (1988) A simple technique for quantitation of low levels of DNA damage in individual cells. Exp Cell Res 175(1):184-191. https://doi.org/10.1016/00144827(88)90265-0

Tice RR, Agurell E, Anderson D, Burlinson B, Hartmann A, Kobayashi H, Miyamae HY, Rojas E, Ryu JC, Sasaki YF (2000) Single cell gel/ comet assay: guidelines for in vitro and in vivo genetic toxicology testing. Environ Mol Mutagen 35:206-221

Toccalino PL, Gilliom RJ, Lindsey BD, Rupert MG (2014) Pesticides in groundwater of the United States: decadal-scale changes, 19932011. Groundwater 52(S1):112-125. https://doi.org/10.1111/gwat. 12176

WAP. World Agricultural Pesticides (2014) Industry market research for business leaders, strategists, decision makers, 399-411. The Freedonia Group, Inc. 767 Beta Drive. Cleveland, OH, pp 44143 2326

Zhong G, Tang J, Xie Z, Mi W, Chen Y, Möller A, Sturm R, Zhang G, Ebinghaus R (2015) Selected current-use pesticides (CUPs) in coastal and offshore sediments of Bohai and yellow seas. Environ Sci Pollut Res 22(3):1653-1661. https://doi.org/10.1007/s11356-0142648-7 